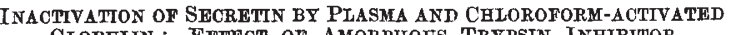
GLOBDLIN : EFFRCT OF AMORPHOUS TRYPSIN INHIBITOR

\begin{tabular}{|c|c|c|}
\hline & Experiment* & $\begin{array}{l}\text { Drop response } \\
\text { to injection }\end{array}$ \\
\hline $\operatorname{Dog} 1$ & $\begin{array}{l}\text { Control secretin }(100 \mu \mathrm{gm} .) \\
\text { Plasma }(a)+\text { secretin }(100 \mu \mathrm{gm} .) \\
\text { Chloroform-activated globulin from }(a) \\
1: 7 \text { dilution + secretin (100 } \mu \mathrm{gm} .) \\
\text { Chloroform-activated globulin + secretin } \\
\text { (100 } \mu \mathrm{gm} .)+ \text { amorphous trypsin } \\
\text { inhibitor }\end{array}$ & $\begin{array}{r}20 \\
18 \\
8 \\
18\end{array}$ \\
\hline $\operatorname{Dog} 2$ & $\begin{array}{l}\text { Control secretin }(200 \mu \mathrm{gm} .) \\
\text { Plasma }(b)+\operatorname{secretin}(200 \mu \mathrm{gm} .) \\
\text { Plasma }(b)+\text { secretin }(200 \mu \mathrm{gm} .)+ \\
\quad \text { amorphous trypsin inhibitor }\end{array}$ & $\begin{array}{r}15 \\
1 \\
9\end{array}$ \\
\hline
\end{tabular}

* The secretin solutions injected into Dogs 1 and 2 were incubated for $\frac{1}{2} \mathrm{hr}$. and $1 \mathrm{hr}$. respectively.

Hammarsten and Ågren ${ }^{7}$ found that secretin prepared according to their methods was labile in the presence of proteolytic enzymes. Our experiments, therefore, are in accord with their observations.

The mechanism of inactivation by 'secretinase' does not appear to involve the liberation of aminoacids, since these could not be detected when plasma of secretin inactivated by chloroform-activated globulin was examined by the sensitive technique of paper-partition chromatography. Unfortunately, the solubility of our secretin at $p \mathrm{H} 6.8$ was not sufficiently great to enable measurements by indirect dilatometry ${ }^{8}$ of any volume changes in the presence of plasma.

It is of interest to note that chloroform-activated globulin inactivates vasopressin but does not affect oxytocin or hypertensinogen?. The extension of the approach outlined above might well be of value in the investigation of the reported blood inactivation of other hormones such as pancreozymin ${ }^{10}$ and cholecystokinin ${ }^{11}$.

Facilities provided for the animal assays by Dr. W. T. Agar, of the Department of Physiology, are gratefully acknowledged.

Department of Biochemistry,

University of Melbourne.

$$
\text { Dec. } 22 .
$$

1 Greengard, Stein and Ivy, Amer, $J$. Physiol, 133, 121 (1941).

'Greengard, Stein and Ivy, Amer. J. Phyziol., 134, 245 (1941).

'Greengard and Ivy, Amer. J. Physiol., 124, 427 (1938).

- Christensen and McLeod, J. Gen. Physiol, 28, 559 (1945).

Tauber, Kershaw and Wright, J. Biol. Chem., 179, 1155 (1949).

${ }^{B}$ Macfarlane and Pilling, Nature, 159, 779 (1947).

'Hammarsten and Ågren, J. Physiol., 90, 330 (1937).

B Linderstrom-Lang and Lanz, C.R. Carlsberg Lab., Sér. Chim., 21 24 (1938). - Croxatto Badia and Croxatto, Proc. Soc. Exp. Biol. and Med., 69,
422 (1948).

10 Harper and Raper, J. Physiol., 102, 115 (1943).

${ }^{11}$ Greengard, Stein and Ivy, Amer. J. Physiol., 134, 733 (1941).

\section{Action of Beryllium on Cells cultivated in vitro; Effect on Mitosis}

THE biological action of beryllium salts has lately aroused interest among embryologists ${ }^{1-3}$ and pathologists ${ }^{4}$. We have investigated the effect of beryllium (sulphate) acting for one to four days on tissue cultures of connective tissue and skeletal muscles (chick embryos). The final concentration varied from $M / 400$ to $M / 10^{8}$.

With high dosage, the growth of the cultures is much inhibited or even stopped within $24 \mathrm{hr}$. With intermediate concentration, the growth is slowed down, markedly after two or three days. With low dosage $\left(M / 10^{5}\right.$, for example), there is practically no action for the first two days, and later the inhibition remains slight.

On fixed and stained cultures, the decrease in the number of mitoses and the relatively high number of round metaphase cells are striking. A few mitoses show chromosomic alterations; others are pyenotic.

In living cultures observed with phase contrast at $38^{\circ}$, a few cells appear to undergo normal mitosis, whereas in others metaphase, always in spherical cells, is unduly lengthened up to several hours. These metaphases can then follow three different courses: they rarely undergo anaphase and telophase and divide into two apparently normal daughter cells; more often, either they degenerate and become pycnotic, or, without dividing, change back to elongated cells, and a resting nucleus-with nucleolus and nuclear membrane-reappears directly. There is then, of course, nothing resembling normal anaphase and telophase.

The transformation of fibroblasts and muscular elements into macrophages is abolished when the concentration of beryllium is $M / 10^{4}$ or higher.

The histochemistry of alkaline phosphatase ${ }^{5}$, deoxyribonucleic acid (Feulgen reaction) and ribonucleic acid (methyl-green-pyronin, control with ribonuclease) was also studied in our cultures. This showed mainly a complete inhibition of alkaline phosphatase at concentrations of $M / 3,000$ and higher. The inhibition is already marked at $M / 10,000$. Biochemists have recently shown that beryllium inhibits strongly alkaline phosphatase ${ }^{6}$ in tissue extracts, even at a concentration of $M / 10^{6}$ when pure substances are used?.

The present work shows that inhibition of growth and mitotic abnormalities are produced by long contact with beryllium ions. It is suggested that the chemical mechanism of this action may be through a specific inhibition of enzymes concerned in phosphorus metabolism and probably in nucleoprotein metabolism.

Institut d'Histologie,

Université de Liège, Liège.

Dec. 23.

1 Needham, A. E., Proc. Zool. Soc., 3, 59 (1941).

2 Thornton, C. S., J. Morphol., 84, 459 (1949).

'Tuchmann-Iuplessis, H., Bull. Hist. App., 27, 116 (1950).

- Sixth Saranak Lake Symposium of the Saranak Lab of the Trudeau Found. (Ed. P. B. Hoeber, New York, 1950).

${ }^{8}$ Chèvremont, M., and Firket, H., Arch. Biol., 60, 441 (1949).

- Klemperer, F. W., Miller, J. M., and Hill, C. J., J. Biol. Chem., 180 281 (1949). Grier, R. S., Hood, M. B., and Hoagland, M. B., ibid., 180, 289 (1949).

7 Aldridge, W. N., Nature, 165, 772 (1950).

\section{Effect of Diet on Toxicity to Rabbits of the Toxic Factor from 'Agenized' Flour}

THE toxic factor present in 'agenized' flour was isolated ${ }^{1}$ and later synthesized ${ }^{2}$ by Moran and his colleagues at St. Albans. These workers had found that oral doses of about $5 \mathrm{mgm}$. of the $d l$-compound or $2 \mathrm{mgm}$. of the $l$-compound caused convulsions in more than 90 per cent of the rabbits dosed (they used animals of about $600-800 \mathrm{gm}$.). Our first attempts to confirm the convulsive effect were completely negative: doses up to $20 \mathrm{mgm}$. of the $\mathrm{dl}$. compound or $10 \mathrm{mgm}$. of the $l$-compound had no effect whatever in our animals. 